\title{
Thermodynamic and Isotherm Analysis on the Removal of Malachite Green Dye Using Thespesia Populnea Bark
}

\author{
R. PRABAKARAN ${ }^{\$ \#}$ AND S. ARIVOLI* \\ ${ }^{\$}$ Mount Zion College of Engineering and Technology, Pudukkottai Tamilnadu, India \\ "PRIST University Vallam, Thanjore (District), Tamilnadu, India \\ *Department of Chemistry, Thiru-V-Ka, Government Arts College, Thiruvarur, India \\ arivu3636@yahoo.com
}

Received 09 August 2011; Accepted 22 January 2012

\begin{abstract}
Activated carbon was synthesized from Thespesia Populnea Bark, a low cost material, by sulphuric acid activation; it was tested for its ability to eliminate malachite green in aqueous solution. The parameters studied included contact time, initial dye concentration, carbon dose, $\mathrm{pH}$ and temperature. The adsorption followed first order rate equation. In addition, it was found that the adsorption process was described by Freundlich and Langmuir isotherm models. Those models were applied to the equilibrium data. The absorption capacities $\left(\mathrm{Q}_{\mathrm{m}}\right)$ obtained from the Langmuir isotherm plots were $349.20,365.43,476.44$, and $389.96 \mathrm{mg} / \mathrm{g}$ at $30^{\circ}, 40^{\circ}, 50^{\circ}$, and $60^{\circ} \mathrm{C}$, respectively, at an initial $\mathrm{pH}$ 6.0. The temperature variation study showed that the malachite green dye absorption was endothermic and spontaneous with increased randomness at the solid solution interface. The thermodynamic parameters like $\Delta H^{\circ}, \Delta S^{\circ}$, and $\Delta G^{\circ}$ were calculated from the slope and intercept of the linear plots.
\end{abstract}

Keywords: Activated Carbon, Malachite Green, Adsorption Isotherm, Thermodynamic Parameters,

Equilibrium and Kinetics.

\author{
Abbreviation \\ Thespesia Populnea Bark Carbon (TPC) \\ Malachite Green (MG) \\ Adsorption efficiency $\left(\mathrm{Q}_{\mathrm{m}}\right)$ \\ Adsorption energy (b) \\ Adsorption capacity $\left(\mathrm{K}_{\mathrm{f}}\right)$
}




\section{Introduction}

Activated carbon is also called activated charcoal. It was mainly used in gas masks during World War I. Later on it has been proved that activated carbon can remove that unwanted colour impurities, polluted air and waste water. But presently it has been mainly used for environmental cleaning purposes. Activated carbon is generally used as an adsorbent due to its high adsorption capacity, high surface area, micro- porous structure and high degree of surface respectively. The preparation and effective utilization of activated carbon produced from natural plant materials have attracted worldwide attention view of the large disposal problem harmful to the environment. Many investigators have studied the feasibility of using inexpensive alternative materials like pearl, millet husk, date pits, saw and buffing dust of the leather industry, coir pith, crude oil residue, tropical grass, olive stone, pine bark, coconut shell, etc., as carbonaceous precursors for the preparation of activated carbons and for the removal of dyes from water and waste water.

The textile, paper and leather industries consume large quantities of water and produces large volume of waste water from different steps in the dyeing and finishing process ${ }^{1-3}$. Malachite green was chosen as model compound for evaluating the potential of TPC (Thespesia Populnea bark Carbon) to remove the dye from aqueous solutions, which is an organic compound that is used for dyestuff and has emerged as a controversial agent in aquaculture. MG is traditionally used as a dye for materials like leather paper and silk.MG is a member of the triphenylcarbenium salts, classified in the dyestuff industry as triarylmethane dyes. Formally, Malachite Green refers to the chloride salt $\left[\mathrm{C}_{6} \mathrm{H}_{5} \mathrm{C}\left(\mathrm{C}_{6} \mathrm{H}_{4} \mathrm{~N}\right.\right.$ $\left.\left(\mathrm{CH}_{3}\right)_{2}\right)_{2}$ ] $\mathrm{Cl}$. It is highly cytotoxic to mammalian cells and also acts as a liver tumor enhancing agent ${ }^{4}$ the structure of malachite green is shown in Fig (1).

The present research work is an effort to investigate the possibility of using TPC to remove malachite green dye in aqueous solution, since the raw material is nontoxic, cheaper and plentiful. Thespesia Populnea tree is located in Tamilnadu, India. It is popularly known as Puvarasam- kallal or Cilanti in Tamil and Portia tree in English, which belongs to Malvaceae family ${ }^{5}$. Thespesia Populnea Bark is shown in the following figure (2). This study reports the adsorption kinetics and thermodynamics of the activated carbon for the adsorption of malachite green dye.

\section{Materials and methods}

\section{Adsorption Experiments}

\section{Batch equilibrium method}

The experiments were carried out in a batch process at $30,40,50$ and $60^{\circ} \mathrm{C}$.the known weight of activated carbon was added to $50 \mathrm{ml}$ of the dye solutions with an initial concentration of $50 \mathrm{mg} / \mathrm{L}$ to $250 \mathrm{mg} / \mathrm{L}$, which is produced from $1000 \mathrm{mg} / \mathrm{L}$ of malachite green stock solution. The contents were shaken thoroughly using a mechanical shaker with a speed of $120 \mathrm{rpm}$. The residual solution was then filtered at preset time intervals and the concentration of the filtrate was measured. The effect of variables such as dosage of the adsorbent, initial concentration, contact time, initial $\mathrm{pH}$, chloride ion, and temperature were studied thoroughly and reported in the results and discussion part. The physical properties of the prepared activated carbon were studied by standard procedures. The zero point charge and the surface functional groups of the activated carbon were studied by the following methods. 


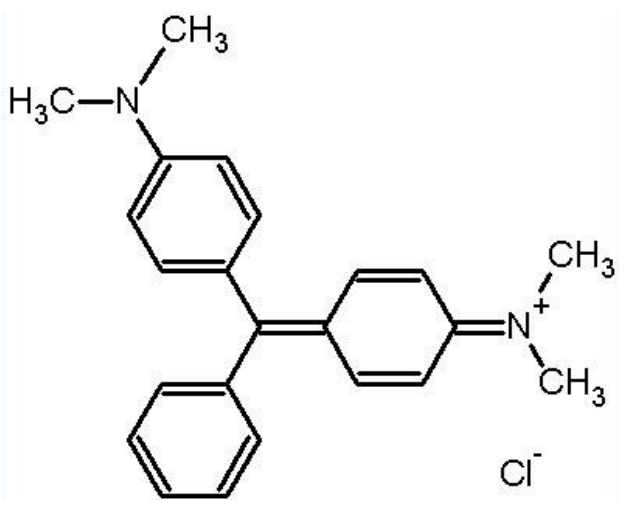

Figure 1. Structure of Malachite Green.

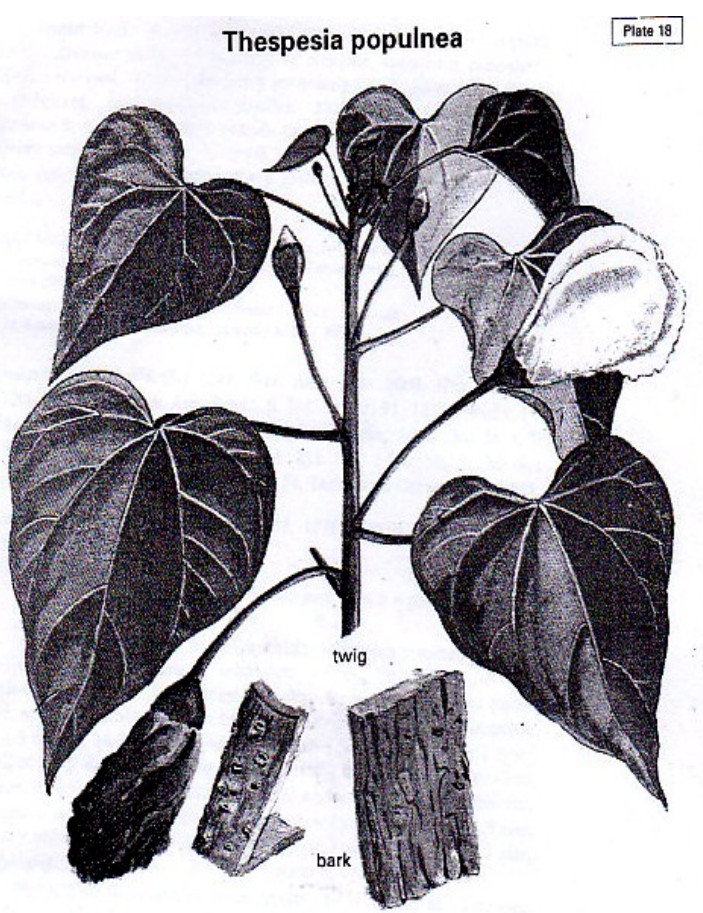

Figure 2. Thespesia Populnea Bark.

\section{Drift method}

The zero point charge of the carbon $\left(\mathrm{pH}_{\mathrm{zpc}}\right)$ was measured using the $\mathrm{pH}$ drift method ${ }^{6}$. The $\mathrm{pH}$ of the solution was adjusted by using $0.01 \mathrm{M}$.sodium hydroxide or hydrochloric acid. Nitrogen was bubbled through the solution at $25^{\circ} \mathrm{C}$ to remove the dissolved carbon dioxide. $25 \mathrm{mg}$ of the activated carbon was added to $50 \mathrm{ml}$ of the solution. After stabilization, the final $\mathrm{pH}$ was recorded. The graphs of final $\mathrm{pH}$ versus initial $\mathrm{pH}$ were used to determine the zero point charge of the activated carbon. 


\section{Results and discussion}

Characteristics of the adsorbent

Characteristics of the adsorbent studied from standard procedures drift method, and titration studies have been listed in Table1.

Table 1. Characteristics of the Adsorbent.

\begin{tabular}{|l|l|}
\hline Properties & TPC \\
\hline Particle size $(\mathrm{mm})$ & 0.041 \\
\hline Density $(\mathrm{g} / \mathrm{cc})$ & 0.3243 \\
\hline Moisture content $(\%)$ & 0.32550 \\
\hline Loss in ignition (\%) & 0.273 \\
\hline pH of aqueous solution & 6.5 \\
\hline
\end{tabular}

Effect of Carbon Dosage and Initial Concentration

The absorption of the malachite green dye on carbon was studied by changing the carbon dose $(10-250 \mathrm{mg} / 50 \mathrm{ml})$ for $100 \mathrm{mg} /$ litre of dye concentration. From fig (3), it is_observed that the percentage of adsorption increased with the increase in the carbon concentration. This was attributed to increased carbon surface area and the availability of more adsorption sites $^{7}$. Hence all studies were carried out with $0.025 \mathrm{mg}$ of adsorbent $/ 50 \mathrm{ml}$ of the varying adsorbate solutions of 50,100,150, 200 and 250. As a result, the amount of MG dye adsorbed per gram reduced with increase in the dosage of TPC is shown in fig (3). This reveals that the direct and equilibrium capacities of MG are functions of the TPC activated carbon dosage. The equilibrium values obtained from the studies are tabulated in Table.2.

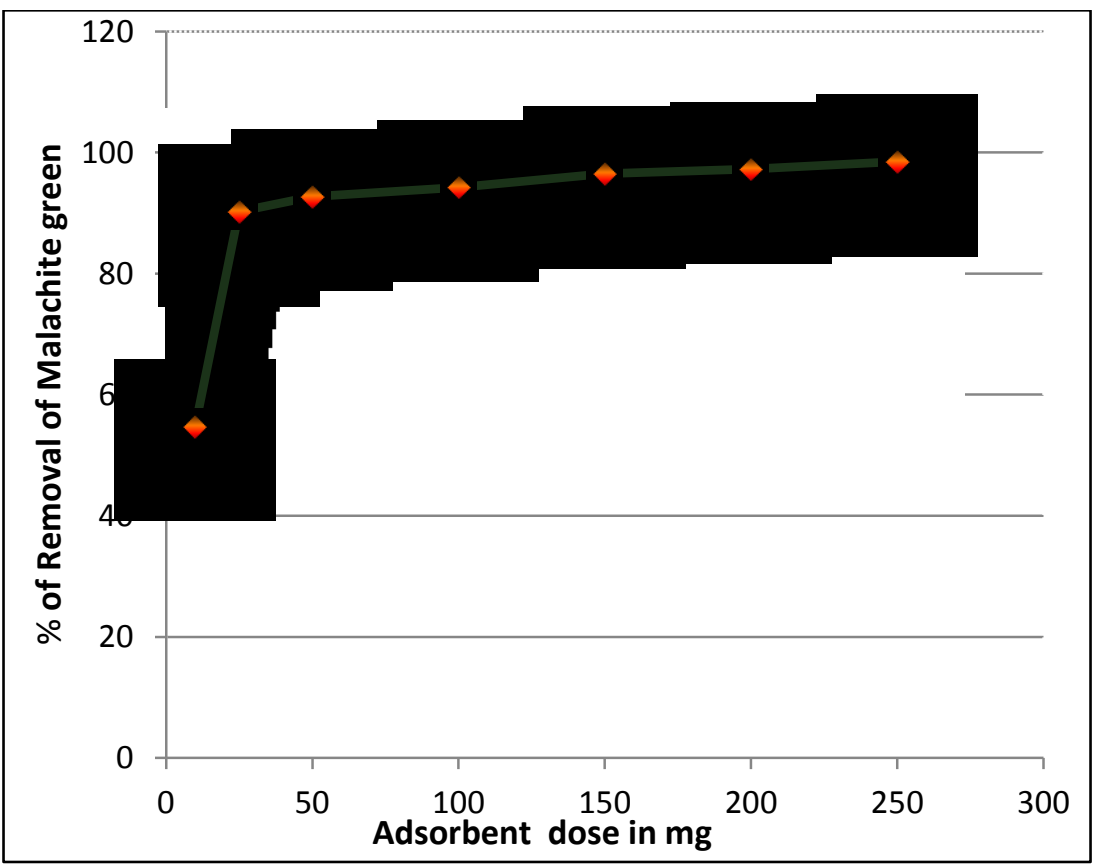

Figure 3. Effect of adsorbent dose on the adsorption of malachite green onto TPC $[\mathrm{MG}]=100 \mathrm{mg} / \mathrm{L}:$ contact time $=60 \mathrm{~min}: \mathrm{pH}=6.5$. 


\section{Effect of contact time}

It is found that the effect of contact time on the amount of dye adsorbed was investigated at $100 \mathrm{mg} / \mathrm{L}$ concentration of the dye as shown in fig.4. It is observed that the percentage removal of dye increases rapidly with an increase in contact time initially, and thereafter, beyond a contact time of about $40 \mathrm{~min}$, no noticeable change in the percentage removal is observed the percentage removals after $40 \mathrm{~min}$ were $90 \%$. Therefore, the optimum contact time is considered to be $40 \mathrm{~min}$. this is also the equilibrium time of the batch adsorption experiments, since beyond a contact time of $40 \mathrm{~min}$, adsorption is not changed. The rapid the removal of dye is observed at the beginning of the contact time due to the percentage of large number of binding sites available for adsorption ${ }^{8}$.

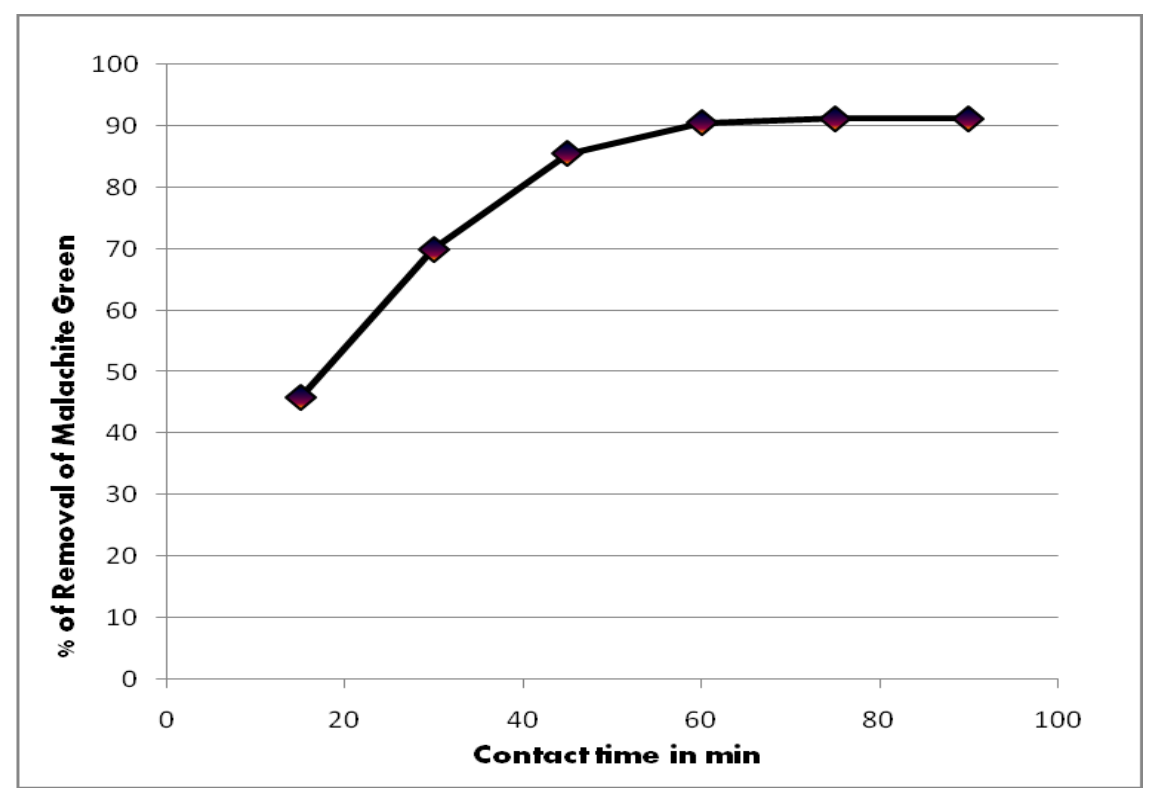

Figure 4. Effect of Contact time on the adsorption of Malachite green onto TPC $[\mathrm{MG}]=100 \mathrm{mg} / \mathrm{L}:$ Adsorbent dose $=25 \mathrm{mg} / 50 \mathrm{ml}: \mathrm{pH}=6.5$.

\section{Adsorption isotherms}

Adsorption isotherms are used to describe how solutes interact with adsorbents, and are critical in optimizing the use of adsorbents. The adsorption models represent the surface properties and affinity of the adsorbent. Several adsorption isotherms are used to evaluate the interaction between the adsorbates and adsorbents.

\section{Langmuir isotherm}

Langmuir sorption isotherm is well known of all isotherms describing sorption ${ }^{9}$ and it has been successfully applied in many sorption processes ${ }^{10}$. It is represented as:

$$
\mathrm{C}_{\mathrm{eq}} / \mathrm{Q}_{\mathrm{eq}}=1 / \mathrm{Q}_{\mathrm{m}} \mathrm{b}+\mathrm{Ceq} / \mathrm{Q}_{\mathrm{m}}
$$

Where $\mathrm{C}_{\mathrm{eq}}$ is the equilibrium concentration of adsorbate in the solution $(\mathrm{mg} / \mathrm{L}), \mathrm{Q}_{\mathrm{eq}}$ is the amount adsorbed at equilibrium $(\mathrm{mg} / \mathrm{g}), \mathrm{Q}_{\mathrm{m}}$ and $\mathrm{b}$ are Langmuir constants related to adsorption efficiency and energy of adsorption, respectively. The linear plots of Ceq/ $\mathrm{Q}_{\text {eq }} \mathrm{vs}$. $\mathrm{C}_{\text {eq }}$ suggest the applicability of the Langmuir isotherms fig (5). The values of $\mathrm{Q}_{\mathrm{m}}$ and $b$ were 
calculated from slope and intercepts of the plots and are listed in Table 3. From the results, it is clear that the value of adsorption efficiency $\mathrm{Q}_{\mathrm{m}}$ and adsorption energy $b$ of the carbon increases on increasing the temperature.

The values can conclude that the maximum adsorption corresponds to a saturated monolayer of adsorbate molecules on adsorbent surface with constant energy and no diffusion of adsorbate in plane of the adsorbent surface. To confirm the favourability of the adsorption process, the separation factor $\left(\mathrm{R}_{\mathrm{L}}\right)$ was determined and given in Table 3.The values were established to be between 0 and 1 and confirm that the ongoing adsorption process is favourable ${ }^{11}$.

\section{Freundlich isotherm}

The Freundlich isotherm is another well known adsorption model, which represents repulsive interactions between adsorbed solute particles ${ }^{12}$. This empirical model is based on adsorption on a heterogeneous surface representing that binding sites are not equivalent and or independent. The Freundlich equation was employed for the adsorption of malachite green dye on the adsorbent. The logarithmic form of Freundlich equation is represented as follows.

$$
\log \mathrm{Q}_{\mathrm{e}}=\log \mathrm{K}_{\mathrm{f}}+1 / n \log C_{\mathrm{e}}
$$

Where $\mathrm{Q}_{\mathrm{e}}$ is the amount of malachite green dye adsorbed $(\mathrm{mg} / \mathrm{g}), C_{e}$ is the equilibrium concentration of dye in solution $(\mathrm{mg} / \mathrm{L})$, and $K_{\mathrm{f}}$ and $n$ are constants which integrate the factors affecting the adsorption capacity and intensity of adsorption, respectively. Linear plots of $\log \mathrm{Q}_{\mathrm{eq}}$ versus $\log C_{\mathrm{eq}}$ shows that the adsorption of malachite green obeys the Freundlich adsorption isotherm, which is given in Figure 6 . The $\mathrm{K}_{\mathrm{f}}$ and $n$ values are given in Table 3 indicate that the increase of negative charges on the adsorbent surface makes electrostatic force like Vanderwaal's between the carbon surface and dye ion. The molecular weight and size either limit or increase the possibility of the adsorption of the dye onto adsorbent. However, the values clearly show the dominance in adsorption capacity.

The intensity of adsorption is an indication of the bond energies between dye and adsorbent, and the possibility of slight chemisorptions rather than physisorption ${ }^{2}, 13,14$. However, the multilayer adsorption of malachite green dye through the percolation process may be possible. The values of $n$ are less than one, indicating the physisorption is much more favourable.

Table 2. Equilibrium parameters for the adsorption of Dye onto activated carbon.

\begin{tabular}{|c|c|c|c|c|c|c|c|c|c|c|c|c|}
\hline \multirow{3}{*}[\mathrm{Mg}]{$^{\circ}$} & \multicolumn{3}{|c|}{$\mathrm{C}_{\mathrm{e}}(\mathrm{mg} / \mathrm{L})$} & \multicolumn{4}{|c|}{$\mathrm{Q}_{\mathrm{e}}(\mathrm{mg} / \mathrm{g})$} & \multicolumn{5}{|c|}{ Dye removed (\%) } \\
\hline & \multicolumn{12}{|c|}{ Temperature ${ }^{\circ} \mathrm{C}$} \\
\hline & 30 & 40 & 50 & 60 & 30 & 40 & 50 & 60 & 30 & 40 & 50 & 60 \\
\hline 50 & 2.252 & 1.841 & 1.463 & 1.146 & 95.496 & 96.316 & 97.09 & 97.72 & 95.49 & 96.31 & 97.09 & 97.72 \\
\hline 100 & 10.42 & 8.832 & 7.337 & 5.678 & 179.16 & 182.8 & 185.3 & 188.6 & 89.58 & 91.42 & 92.66 & 94.32 \\
\hline 150 & 14.84 & 22.75 & 20.88 & 8.236 & 250.3 & 254.4 & 258.3 & 262.6 & 88.43 & 84.83 & 86.11 & 87.52 \\
\hline 200 & 68.1 & 19.14 & 20.82 & 22.63 & 293.8 & 301.7 & 358.3 & 317.3 & 73.40 & 75.44 & 89.58 & 79.33 \\
\hline 250 & 48.24 & 80.03 & 45.45 & 46.54 & 322.5 & 339.9 & 409.2 & 369.3 & 64.50 & 67.98 & 81.80 & 73.88 \\
\hline
\end{tabular}


Table 3. Langmuir Isotherm, Freundlich Isotherm results and Dimensionless separation factor $\left(\mathrm{R}_{\mathrm{L}}\right)$.

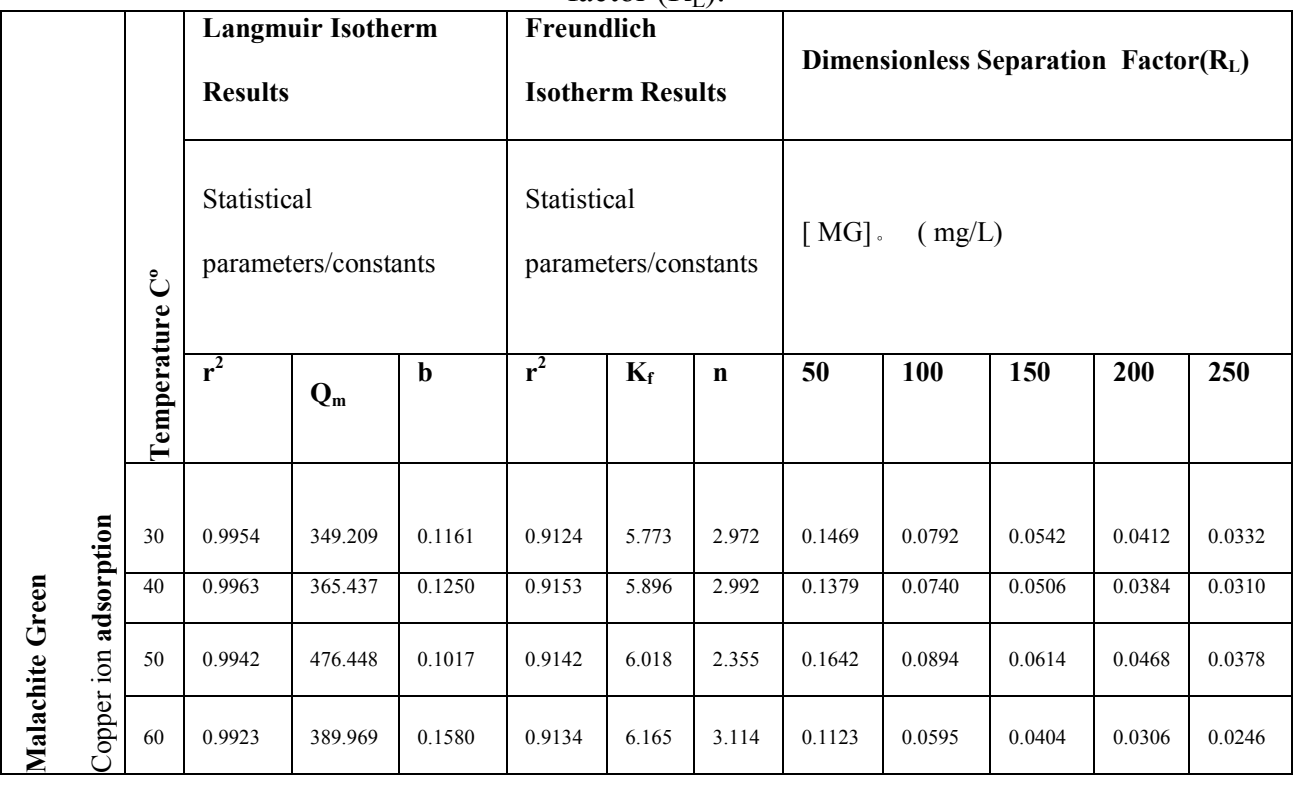

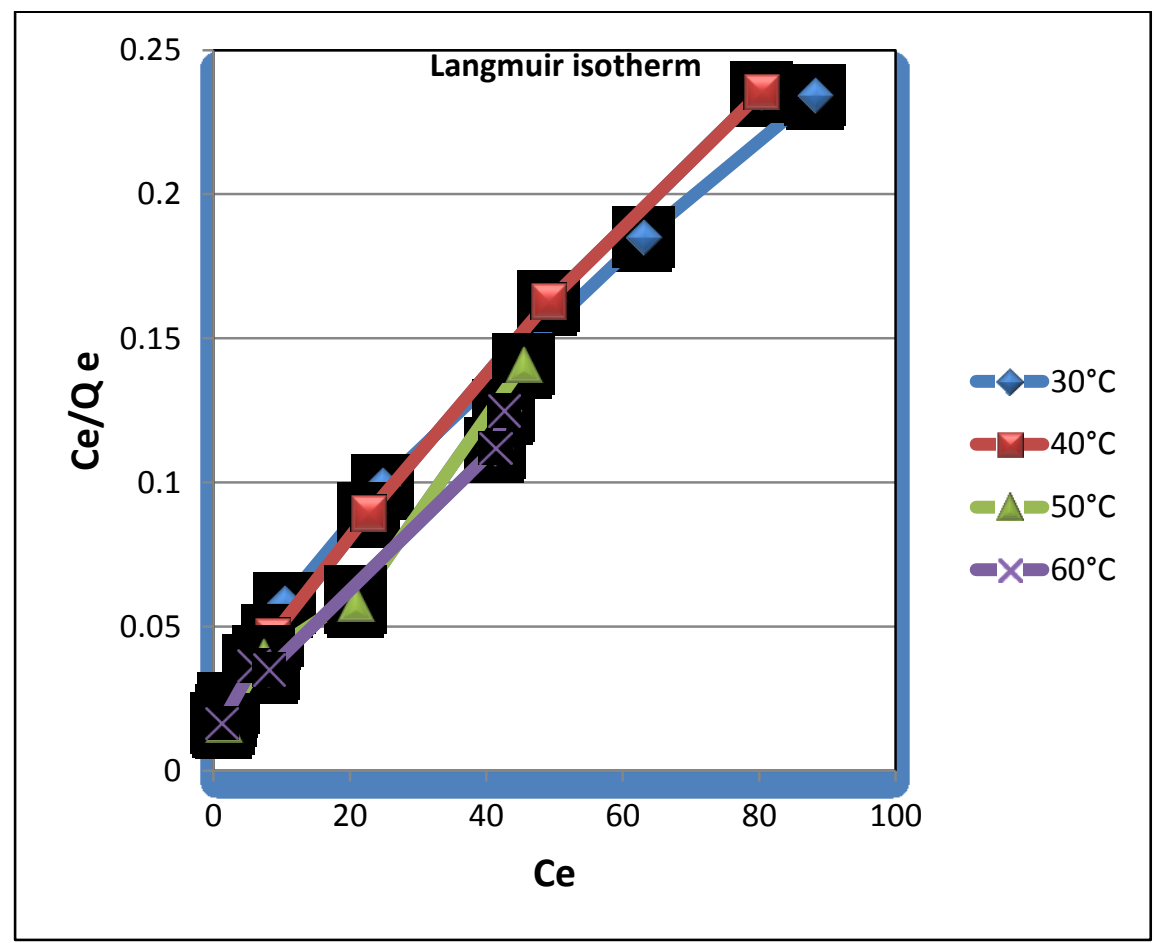

Figure 5. Langmuir Isotherm for the adsorption of malachite green onto TPC. 


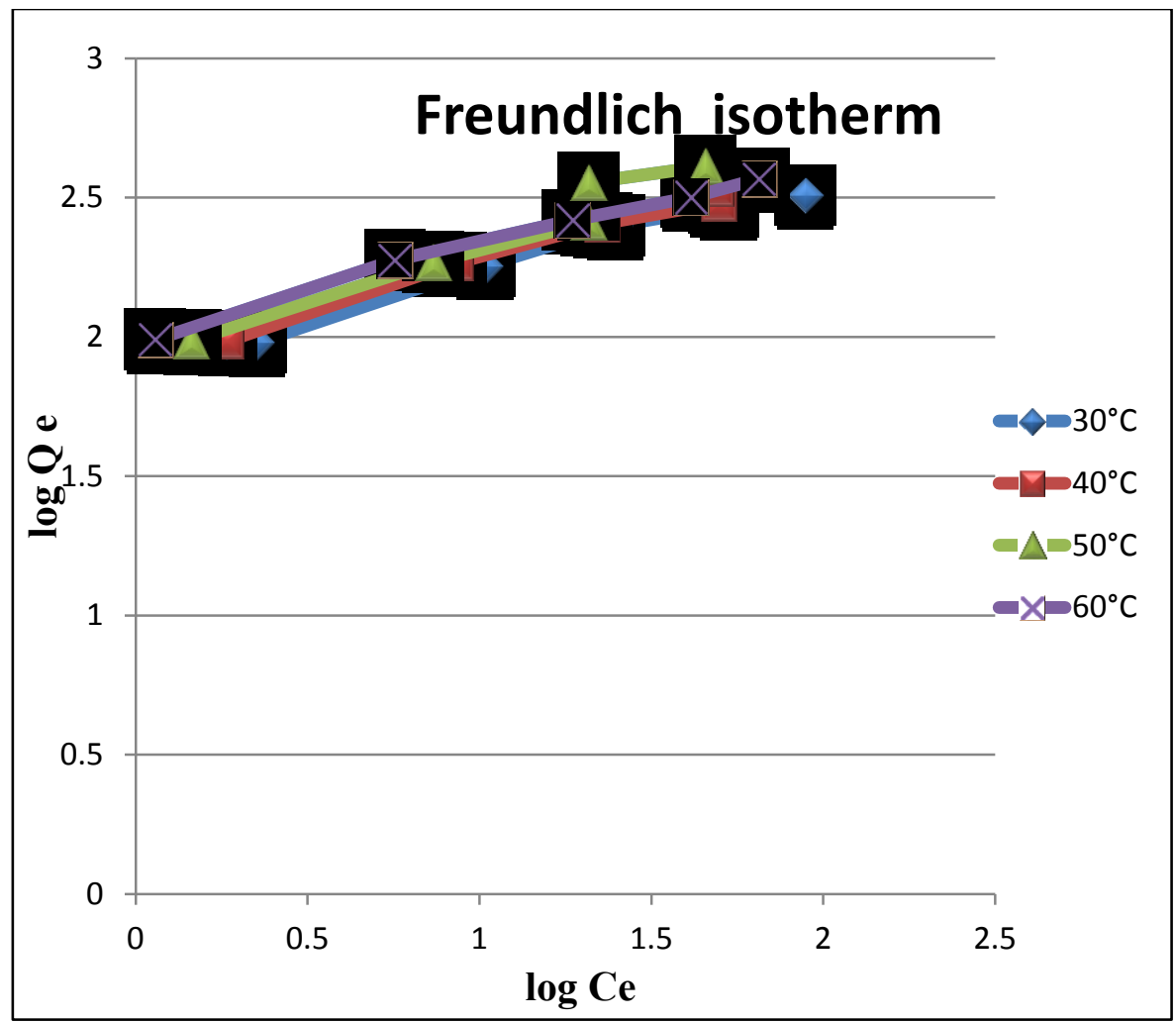

Figure 6. Freundlich Isotherm for the adsorption of malachite green onto TPC.

\section{Effect of temperature}

The effect of temperature was studied in the range of 30 to $60^{\circ} \mathrm{C}$ by keeping the rest parameters such as adsorbate concentration at $100 \mathrm{mg} / \mathrm{L}^{-1}$, the $\mathrm{pH}$ at 6.5 and the adsorbent concentration at $25 \mathrm{mg}$ in $50 \mathrm{ml}$. Adsorption capacity of the carbon increased with increase of the temperature in the system from $30^{\circ} \mathrm{C}$ to $60^{\circ} \mathrm{C}$. Thermodynamic parameters such as change in free energy $\left(\Delta \mathrm{G}^{\circ}\right)(\mathrm{kJ} / \mathrm{mol})$, enthalpy $\left(\Delta \mathrm{H}^{\circ}\right)(\mathrm{kJ} / \mathrm{mol})$ and entropy $\left(\Delta \mathrm{S}^{\circ}\right)$ $(\mathrm{J} / \mathrm{K} /$ 'mol) were determined using the following equations

$$
\begin{gathered}
\mathrm{K}_{0}=\mathrm{C}_{\text {solid }} / \text { Cliquid } \\
\Delta G^{\circ}=-\mathrm{RT} \ln \mathrm{K}_{\mathrm{O}} \\
\log \mathrm{K}_{0}=\Delta S^{\circ} /(2.303 \mathrm{R})-\Delta H^{\circ} /(2.303 \mathrm{RT})
\end{gathered}
$$

Where $\mathrm{K}_{0}$ is the equilibrium constant, $\mathrm{C}_{\text {solid }}$ is the solid phase concentration at equilibrium $(\mathrm{mg} / \mathrm{L}), \mathrm{C}_{\text {liquid }}$ is the liquid phase concentration at equilibrium $(\mathrm{mg} / \mathrm{L}), T$ is the temperature in 
Kelvin, and $R$ is the gas constant. The $\Delta H^{\circ}$ and $\Delta S^{\circ}$ values obtained from the slope and intercept of Van't Hoff plots has been given in Table 4. The values of $\Delta H^{\circ}$ is the range of 1 to $93 \mathrm{~kJ} / \mathrm{mol}$ shows the physisorption. It is found that from results that physisorption is highly favourable for the adsorption of malachite green.

The positive values of $\Delta H^{\circ}$ indicate the endothermic nature of adsorption which governs the possibility of physical adsorption ${ }^{2,7,13,14}$. Because in the case of physical adsorption, while increasing the temperature of the system, the extent of dye adsorption increases, there is no possibility of chemisorption.

The negative values of $\Delta G^{\circ}$ (Table4) indicate that the adsorption is highly favourable and spontaneous. The positive values of $\Delta S^{\circ}$ (Table4) show the increased disorder and randomness at the solid solution interface of malachite green with TPC adsorbent.

Table 4. Equilibrium constant and thermodynamic parameters for the adsorption of Malachite Green onto activated carbon.

\begin{tabular}{|c|c|c|c|c|c|c|c|c|c|c|}
\hline \multirow{3}{*}[\mathrm{MG}]{$^{\circ}$} & \multirow[b]{3}{*}{$\Delta H^{\circ}$} & \multirow[b]{3}{*}{$\Delta S^{\circ}$} & \multicolumn{4}{|c|}{$\mathbf{K}_{0}$} & \multicolumn{4}{|c|}{$\Delta G^{\circ}$} \\
\hline & & & \multicolumn{8}{|c|}{ Temperature (C) } \\
\hline & & & $30^{\circ}$ & $40^{\circ}$ & $50^{\circ}$ & $60^{\circ}$ & $30^{\circ}$ & $40^{\circ}$ & $50^{\circ}$ & $60^{\circ}$ \\
\hline 50 & 19.731 & 90.360 & 21.202 & 26.150 & 33.397 & 42.859 & -7993.7 & -8493.4 & -9421.7 & -10404.0 \\
\hline 100 & 17.962 & 77.060 & 8.5969 & 10.665 & 12.628 & 16.618 & -5419.6 & -6159.7 & -6810.0 & -7781.01 \\
\hline 150 & 9.1894 & 43.715 & 5.0382 & 5.5925 & 6.2040 & 7.0162 & -4073.6 & -4479.6 & -4901.4 & -5393.79 \\
\hline 200 & 17.349 & 66.343 & 2.7664 & 3.0719 & 8.6054 & 3.8398 & -2563.4 & -2920.6 & -5780.0 & -3724.94 \\
\hline 250 & 17.743 & 63.957 & 1.8169 & 2.1234 & 4.4957 & 2.8290 & -1504.3 & -1959.6 & -4036.5 & -2879.18 \\
\hline
\end{tabular}

\section{Effect of $p H$}

The $\mathrm{pH}$ of the aqueous solution is an important controlling parameter in the sorption process. The $\mathrm{pH}$ of the solution was controlled by the addition of $\mathrm{HCI}$ or $\mathrm{NaOH}$. The effect of $\mathrm{pH}$ on the adsorption of malachite green ions on TPC is shown in Figure 7. The uptake of malachite green ions has been minimum at $\mathrm{pH} 3$ and maximum at $\mathrm{pH}$ 6. 5. However, when the $\mathrm{pH}$ of the solution increased (more than $\mathrm{pH} 7$ ), the uptake of malachite green ions also increased; It appears that a change in $\mathrm{pH}$ of the solution results in the formation of different ionic species, and a different carbon surface charge. When the $\mathrm{pH}$ value is lower than 6.5 , the malachite green dyes are able to enter into the pore structure. As the $\mathrm{pH}$ value increased to above 7, the zwitter ions form of malachite green in water may raise the aggregation of malachite green to form a bigger molecular form (dimer) and become unable to enter into the pore structure of the carbon surface. 


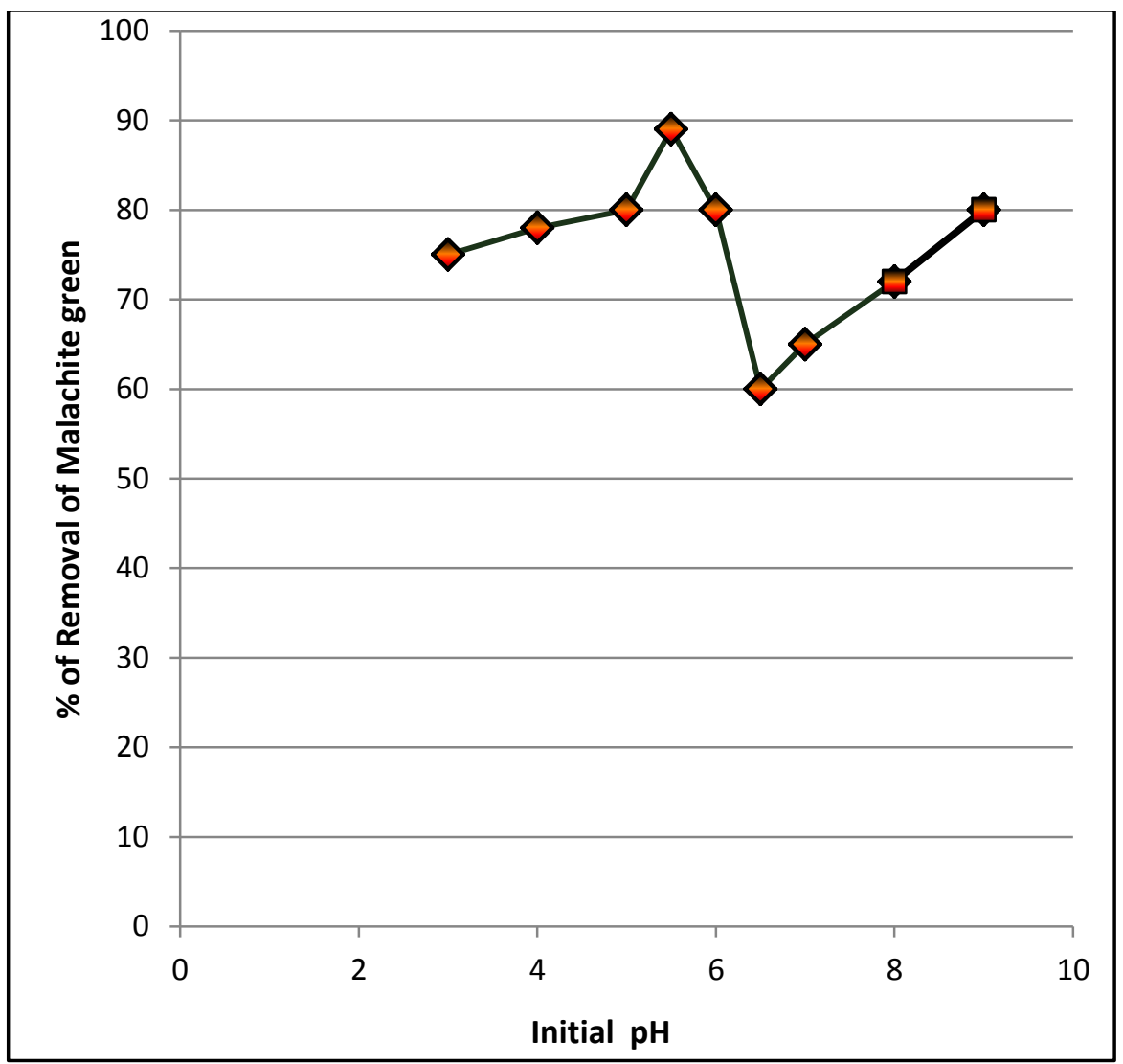

Figure 7. Effect of $\mathrm{pH}$ on the adsorption of malachite green onto TPC.

$[\mathrm{MG}]=100 \mathrm{mg} / \mathrm{L}:$ adsorbent dose

$=25 \mathrm{mg} / 50 \mathrm{ml}$ : contact time $=60 \mathrm{~min}$.

The greater aggregation of the zwitter ionic form is due to the attractive electrostatic interaction between the ionic groups of the monomer. When the $\mathrm{pH}$ value is more than 9 , the existence of TPC surface creates a competition between ionic dyes and decreases the aggregation of malachite green. It also causes an increase in the adsorption of malachite green ions on the carbon surface. The effect of the charge on the carbon surface, and the electrostatic force of attraction and repulsion between the carbon surface and the malachite green ions, cannot explain the outcome ${ }^{13,15}$.

\section{Effect of the Ionic Strength}

The effect of sodium chloride on the adsorption of malachite green on TPC is shown in Figure 8 . The low concentrate $\mathrm{NaCl}$ solution had little influence on the adsorption capacity. When the concentration of $\mathrm{NaCl}$ increases, the ionic strength also increases. At higher ionic strength, the adsorption of malachite green will be raised to the partial neutralization of the positive charge on the carbon surface and a consequent compression of the electrical double layer by the $\mathrm{Cl}^{-}$anion. The chloride ion also enhances adsorption of malachite green dye ion by pairing their charges, and hence reducing the repulsion between the malachite green dyes adsorbed on the surface. This initiates carbon to adsorb more positive malachite green dye ions $^{16}$. 


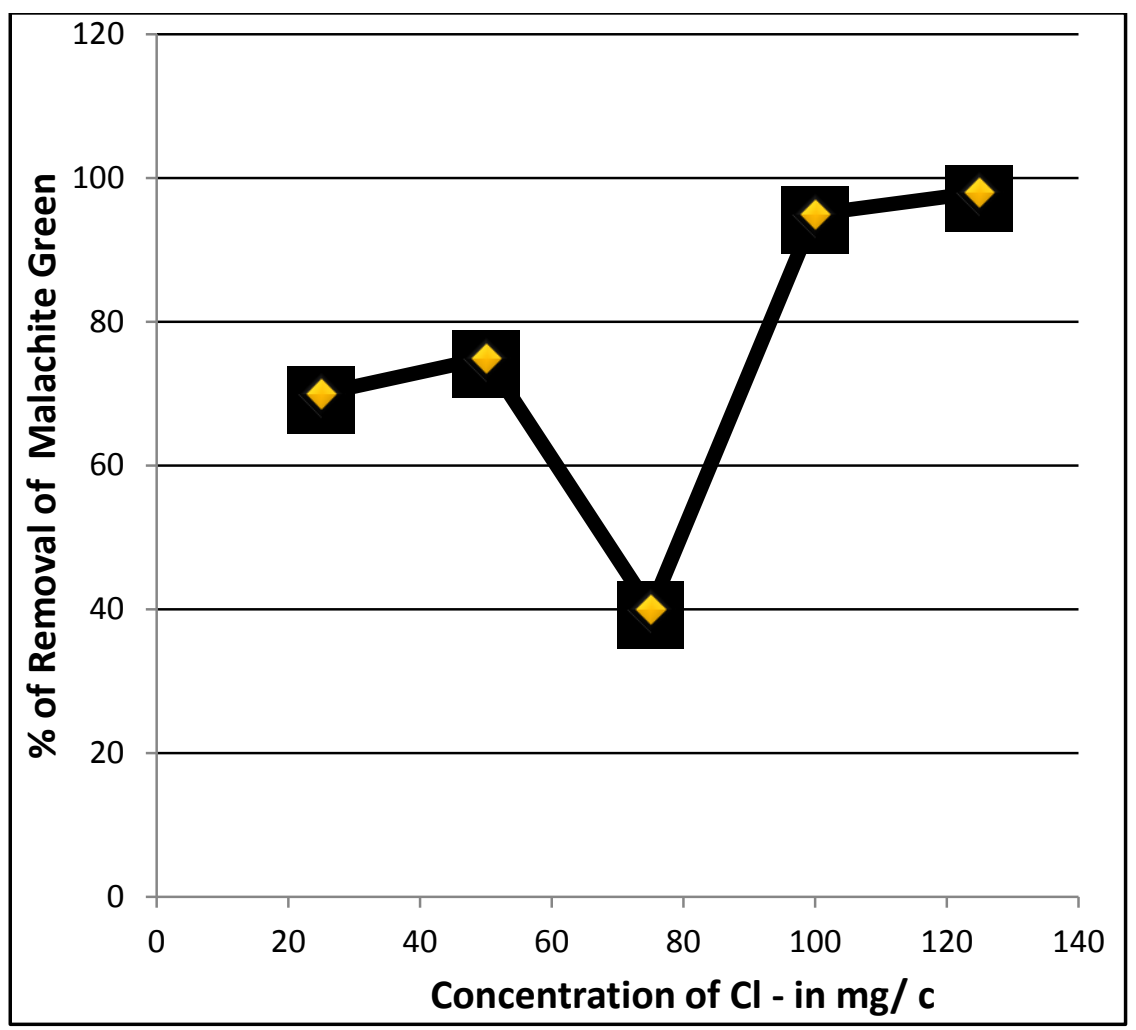

Figure 8. Effect of other ions on the removal of malachite green dyes.

$[\mathrm{MG}]=100 \mathrm{mg} / \mathrm{L}:$ adsorbent dose

$=25 \mathrm{mg} / 50 \mathrm{ml}$ : contact time $=60 \mathrm{~min}$.

\section{Adsorption Kinetics}

There are essentially three steps in the adsorption process by porous adsorbents ${ }^{17}$. [1] solute transfer from the bulk solution to the external surface of the sorbent through liquid boundary layer(film resistance); [2] solute transfer from the sorbent surface the intraparticle actives sites(internal particle resistance); and [3] interaction of the solute with available sites on both the external and internal surface of the adsorbent (reaction resistance). One or more of the above mentioned steps may control the rate at which the solute is adsorbed on to the adsorbent. In this study, the kinetic of the dye removal were carried out to understand behavior of the chosen carbon. The adsorption of the malachite green dye from an aqueous solution follows reversible first order kinetics, when a single species is considered on a heterogeneous surface. The heterogeneous equilibrium between the dye solution and the activated carbon have been expressed as

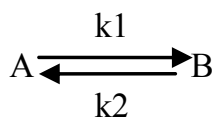

Where $k_{1}$ is the forward rate constant and $k_{2}$ is the backward rate constant. $A$ represents the dye remaining in the aqueous solution and $B$ represents the dyes adsorbed on the surface of 
the activated carbon. The equilibrium constant $\left(\mathrm{K}_{0}\right)$ is the ratio of the concentration adsorbate in adsorbent in aqueous solution $\left(\mathrm{K}_{0}=\mathrm{k}_{1} / \mathrm{k}_{2}\right)$.

To study the kinetics of the adsorption process, the following kinetic equation proposed by Natarajan and Khalaf, as cited in literature, were employed.

$$
\log \mathrm{C}_{0} / \mathrm{C}_{\mathrm{t}}=(\operatorname{Kad} / 2.303) \mathrm{t}
$$

Where $\mathrm{C}_{0}$ and $\mathrm{C}_{\mathrm{t}}$ are the concentration of the dye (in $\mathrm{mg} / \mathrm{L}$ ) at the time of zero and time $\mathrm{t}$ respectively. The rate constants $\left(\mathrm{K}_{\mathrm{ad}}\right)$ for the adsorption processes are calculated from the slope of the linear plots of $\log \mathrm{C}_{0} / \mathrm{C}_{\mathrm{t}}$ versus $\mathrm{t}$ for different concentrations and temperatures. The determination of rate constants as evaluated in literature is given by the following equation

$$
\mathrm{K}_{\mathrm{ad}}=\mathrm{k}_{1}+\mathrm{k}_{2}=\mathrm{k}_{1}+\left(\mathrm{k}_{1} / \mathrm{K}_{0}\right)=\mathrm{k}_{1}\left[1+1 / \mathrm{K}_{0}\right]
$$

The overall rate constant $k_{\mathrm{ad}}$ for the adsorption of dye at different temperatures is calculated from the slopes of the linear Natarajan-Khalaf plots. The rate constant values are given in Table 5 show that the rate constant $\left(\mathrm{k}_{\mathrm{ad}}\right)$ increases with increase in temperature, suggesting that the adsorption process is endothermic in nature. The rate constants for the forward and reverse processes collected in Table 5 shows that the forward rate constant is much higher than the reverse rate constant at all initial concentrations and temperatures, suggesting that the rate of adsorption is clearly dominant ${ }^{11,18}$.

\section{Desorption Studies}

Desorption studies assist to illuminate the nature of adsorption and recycling of the spent adsorbent. The effect of various reagents used for desorption studies indicate that hydrochloric acid is a better reagent for desorption. Desorption of malachite green dye by dilute mineral acid indicates that the dyes were adsorbed onto the activated carbon through physisorption $^{19}$.

Table 5. Rate constants for the adsorption of malachite green dyes $\left(\mathrm{k}_{\mathrm{ad}}, \mathrm{min}^{-1}\right)$ and the

\begin{tabular}{|c|c|c|c|c|c|c|c|c|c|c|c|c|}
\hline \multicolumn{13}{|c|}{ Temperature $\left(\mathrm{C}^{\circ}\right)$} \\
\hline \multirow[t]{2}{*}[\mathbf{Mg}]{$^{\circ}$} & \multicolumn{4}{|l|}{$\mathbf{k}_{\mathrm{ad}}$} & $\mathbf{k}_{1}$ & $\mathbf{k}_{\mathbf{2}}$ & $\mathbf{k}_{1}$ & $\mathbf{k}_{2}$ & $\mathbf{k}_{1}$ & $\mathbf{k}_{\mathbf{2}}$ & $\mathbf{k}_{1}$ & $\mathbf{k}_{2}$ \\
\hline & $30^{\circ}$ & $40^{\circ}$ & $50^{\circ}$ & $60^{\circ}$ & \multicolumn{2}{|l|}{$30^{\circ}$} & \multicolumn{2}{|l|}{$40^{\circ}$} & \multicolumn{2}{|l|}{$\mathbf{5 0}^{\circ}$} & \multicolumn{2}{|l|}{$60^{\circ}$} \\
\hline 50 & 0.0389 & 0.0348 & 0.0391 & 0.0533 & 0.024 & 0.0017 & 0.033 & 0.0012 & 0.037 & 0.0011 & 0.052 & 0.0012 \\
\hline 100 & 0.0226 & 0.0220 & 0.0241 & 0.0275 & 0.020 & 0.0023 & 0.020 & 0.0018 & 0.022 & 0.0017 & 0.026 & 0.0015 \\
\hline 150 & 0.0140 & 0.0148 & 0.0160 & 0.0169 & 0.011 & 0.0023 & 0.012 & 0.0022 & 0.013 & 0.0022 & 0.014 & 0.0021 \\
\hline 200 & 0.0096 & 0.0103 & 0.0108 & 0.0117 & 0.007 & 0.0025 & 0.007 & 0.0025 & 0.009 & 0.0011 & 0.009 & 0.0024 \\
\hline 250 & 0.0080 & 0.0076 & 0.0086 & 0.0097 & 0.005 & 0.0028 & 0.005 & 0.0024 & 0.007 & 0.0016 & 0.007 & 0.0025 \\
\hline
\end{tabular}
constants for forward $\left(\mathrm{k}_{1}, \mathrm{~min}^{-1}\right)$ and reverse $\left(\mathrm{k}_{2}, \mathrm{~min}^{-1}\right)$ process. 


\section{Conclusion}

TPC has been successfully used to produce high quality activated carbon because of its experimental data associated practically well by the Langmuir and Freundlich adsorption isotherms and the isotherm parameters were calculated. The low as well as high $\mathrm{pH}$ value paves the way to the optimum amount of adsorption of the dye. The adsorption of malachite green is increased with increasing ionic strength and temperature. The dimensionless separation factor $\left(R_{L}\right)$ showed that the activated carbon could be used for the removal of malachite green dye from aqueous solution. The values of $\Delta H^{\circ} \Delta S^{\circ}$ and $\Delta \mathrm{G}^{\circ}$ show that the carbon employed has considerable potential to remove malachite green dye from aqueous solution. Our future work deals with the evaluation and performance of various biomasses for the removal of malachite green.

\section{References}

1. Ramesh Bapu B, Parande A.K, Ragu S and Premkumar T Cotton Textile Processing: waste generation and effluent treatment, J.cotton Sci., 2007, 11, 14-153.

2. Arivoli $S$ and Hema $M$ "Comparative Study on the Adsorption Kinetics and Thermodynamics of Dyes onto Acid Activated Low Cost Carbon", Intern .J Phvs Sci., 2007, 2, pp. 10-17.

3. Ho, Y.S. and McKay G., "The Kinetics of Sorption of Basic Dyes From Aqueous Solution by Sphagnum Moss Peat", Can J. Chem. Eng., 1998. 76, 4, 822-7,

4. Adina Raducan, Alexandra Olteanu, Mihaela Puiu, Dumitru Oancea "Influence of surfactants on the fading of malachite green" Central European Journal of Chemistry, 2008 ,

5. Varier's P.S “Indian Medicinal Plants”, Orient Longman Ltd, Chennai Vol.V p 281

6. Jia Y.F and Thomas K.K. "Adsorption of Metal Ion on Nitrogen Surface Functional Groups in Activated Carbon, Langmuir. 2002. 18, Pp. 470-478.

7. Namasivayam C and Yamuna R. T "adsorption of direct dye red dye biogas residual slurry", environ. Pollut.,1995, 89, p.1

8. Namasivayam C, Muniasamy N, Gayathri K Rani M and Renganathan K "Removal of Dyes from Aqueous solution by cellulosic waste orange peel”, Biores. Technol.,1996, 57, p.37.

9. Lanqmuir, I. The adsorption of gases on plane surfaces of glass, mica and platinum.J.Am.Chem.Soc.,1918, 40, 1361-1403.

10. Beyazit N, Ergun O.N, and Peker I Cu (II) removal from aqueous solution using Dogantepe (Amasya) zeolite. Int. I. Environ. Pollut., 2003, 19,150-159.

11. Arivoli S, Kalpana K, Sudha R and Rajachandrasekar T, "Comparative Study on the Adsorption Kinetics and Thermodynamics of Metal Ions onto Acid Activated Low Cost Carbon", EJ Chem., 2007, 4, pp. 238-254.

12. Freundlich, H.Ueber die Adsorption in Loesungen. Z.Phys. Chem. 1907, 57. 385-470.

13. Arivoli S, Viji Jam M, and Rajachandrasekar T "Cobalt Adsorption on a Low Cost Carbon-Kinetic, Equilibrium and Mechanistic Studies", Mat Sci Res India., 2006, 3, pp. 241-250.

14. Geundi E.I, S.M., "Colour Removal from Textile Effluents-by Adsorption Techniques" Water Res., 1991, 25, 271-273.

15. Krishna D.G and Bhattacharyya G, "Adsorption of Methylene Blue on Kaolinite”, Appl Clay Sd., 2002, 20, p. 295.

16. Vadivelan V and Vasanthkumar K "Equilibrium, Kinetics, Mechanism and Process Design for the Sorption of Methylene Blue onto Rice Husk", J Colloid InterfSci., 2005,286, p. 91. 
17. McKay G, The adsorption of basic dye onto silica from aqueous -solution solid diffusion- model, Chem. Eng. Sci.,1984, 39, 129-138

18. Arivoli S and Hema M, Intern J Phys Sci., 2007, 2, 10-17

19. Ho, Y.S. and McKay G, "Pseudo second order model for sorption process", Process Biochemistry., 1999. 34: 45 1- 465. 


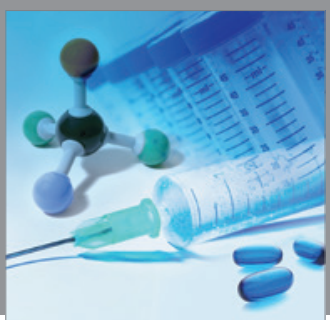

International Journal of

Medicinal Chemistry

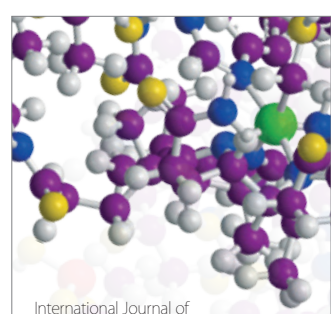

Carbohydrate Chemistry

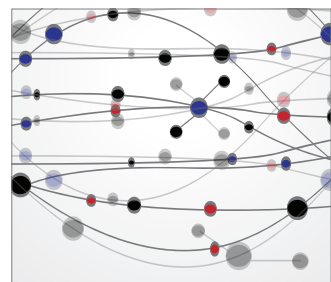

The Scientific World Journal
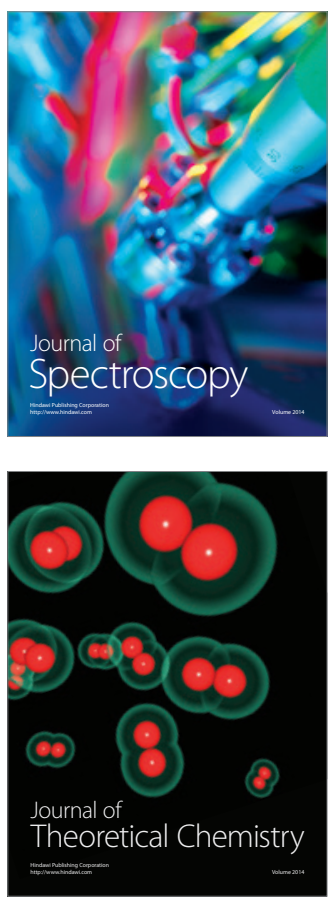
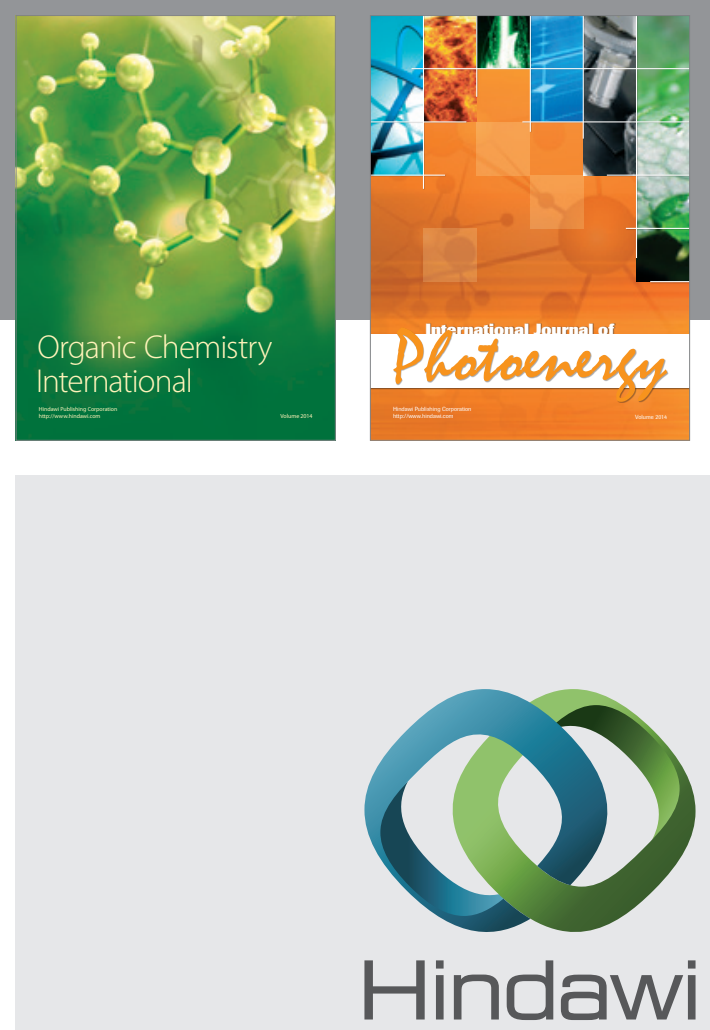

Submit your manuscripts at

http://www.hindawi.com
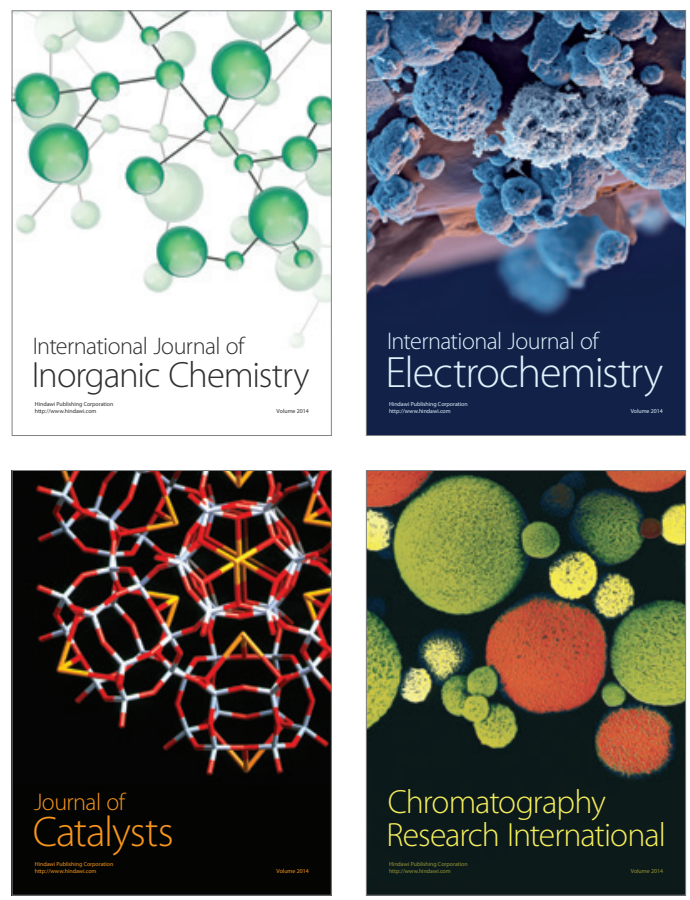
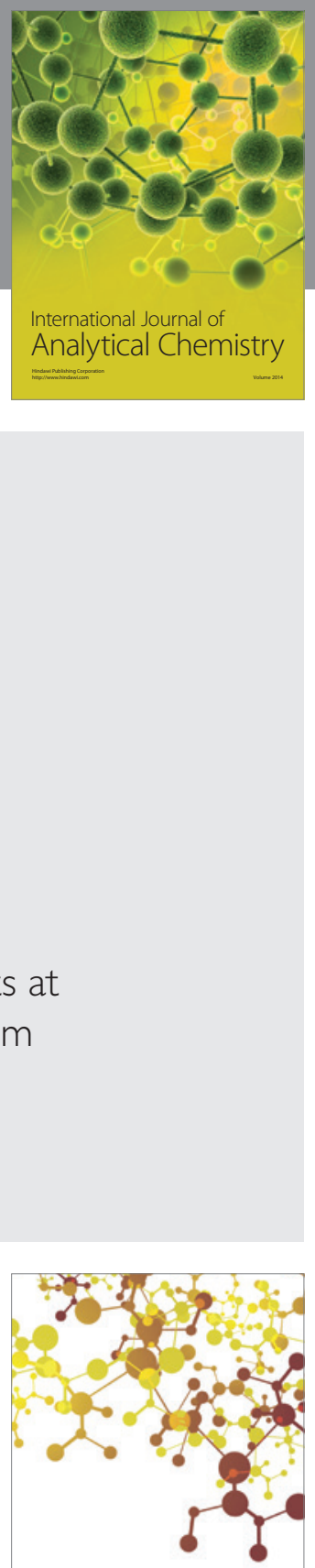

Journal of

Applied Chemistry
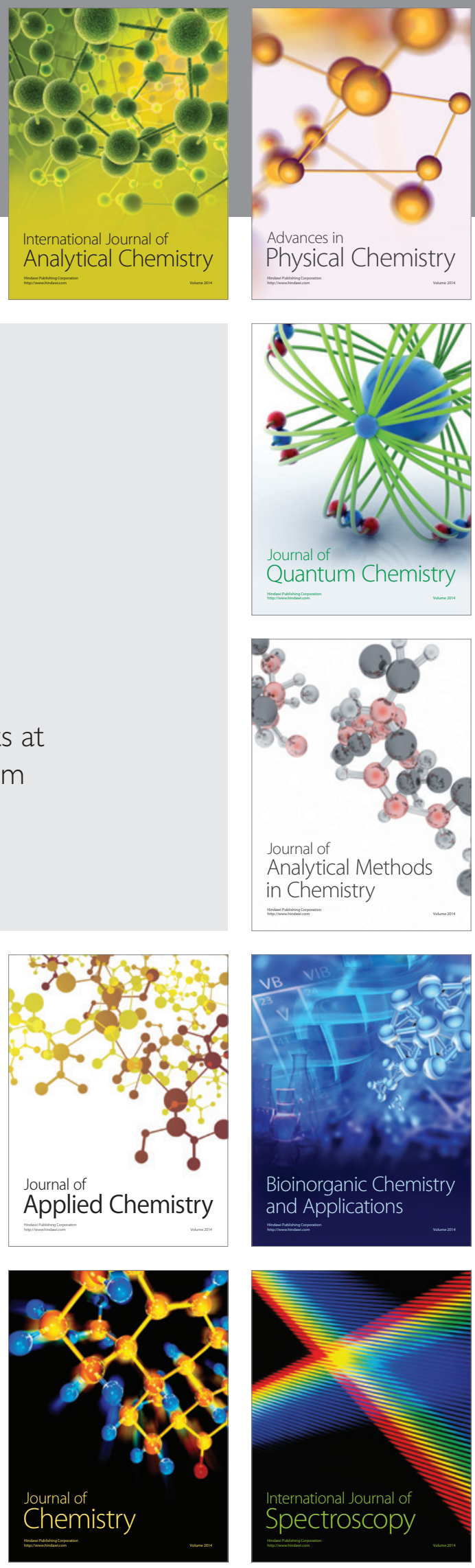